\title{
Tied Ridges and Better Cotton Breeds for Climate Change Adaptation
}

\author{
R. Mandumbu, C. Nyawenze, J. T. Rugare, G. Nyamadzawo, \\ C. Parwada, and H. Tibugari
}

\section{Contents}

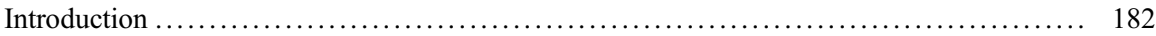

Characteristics of Cotton Growing Areas in Zimbabwe ............................ 185

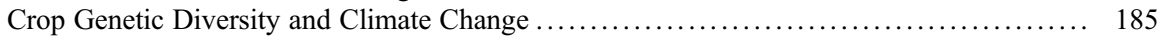

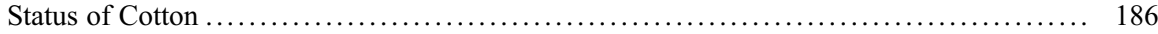

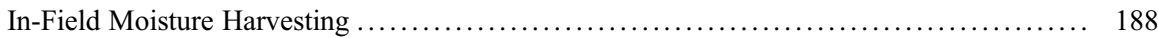

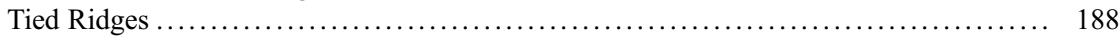

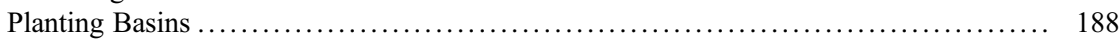

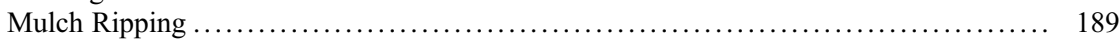

This chapter was previously published non-open access with exclusive rights reserved by the Publisher. It has been changed retrospectively to open access under a CC BY 4.0 license and the copyright holder is "The Author(s)". For further details, please see the license information at the end of the chapter.

\author{
R. Mandumbu ( $₫)$ \\ Crop Science Department, Bindura University of Science Education, \\ Bindura, Zimbabwe \\ e-mail: rmandumbu@gmail.com \\ C. Nyawenze \\ Cotton Company of Zimbabwe, Harare, Zimbabwe \\ J. T. Rugare \\ Department of Crop Science, University of Zimbabwe, Harare, Zimbabwe \\ G. Nyamadzawo \\ Department of Environmental Science, Bindura University of Science Education, \\ Bindura, Zimbabwe \\ C. Parwada \\ Department of Horticulture, Women's University in Africa, Harare, Zimbabwe \\ H. Tibugari \\ Department of Plant and Soil Sciences, Gwanda State University, Gwanda, Zimbabwe
}




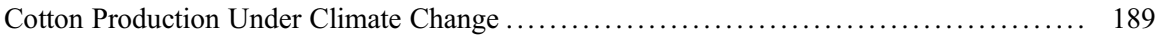

Effects of Water Harvesting on Soil Moisture Content ............................. 189

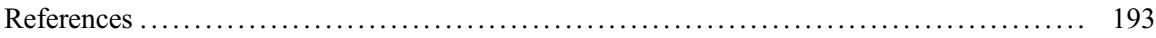

\section{Abstract}

Climate change and variability is already reducing agricultural productivity and opportunities for employment, pushing up food prices and affecting food availability and production of formerly adapted crop types. Such is the case in cotton production in Zimbabwe, where it was the only viable commercial crop in marginal areas. As a form of adaptation, there is need for African farmers to have a range of agricultural techniques as coping strategies and tactics to enable sustainable production of crops and deal with extreme events. Such techniques include water conservation and introduction of new adapted crop genetics to cope with the new environment. The emerging trends in climate change will force farmers to adopt new crops and varieties and forms of agricultural production technologies. The objective of this study is to determine the contribution of combining in-field water harvesting and early maturing cotton varieties in curbing drought in cotton in semiarid Zimbabwe. The results show that both water harvesting in form of planting basins significantly $(P<0.05)$ increased boll number and branch number of cotton across all varieties. The varieties M577 and M567 out-performed the conventional varieties in early growth, branch number, and boll number. Tied contour ridges gave a significantly $(P<0.05)$ higher moisture content in $0-5 \mathrm{~cm}$ and the 6-10 cm depth compared to conventional tillage. The new varieties displayed early phenological development. Despite the existence of rainfall gaps, the in-field water harvesting techniques captured enough moisture and prevented moisture losses through runoff which resulted successful flowering and fruiting in the short varieties compared to conventional tillage on conventional varieties. In this regard, water harvesting and early maturing varieties offer considerable hope for increasing crop production in arid and semiarid areas of Zimbabwe.

\section{Keywords}

Climate change $\cdot$ Adaptation $\cdot$ Water conservation $\cdot$ Cotton $\cdot$ Semiarid

\section{Introduction}

Africa is regarded as having climates that are among the most viable in the world on seasonal and decadal time scales (UNFCCC 2007). Floods and droughts can occur in the same area within months from each other. Of the total additional people at risk of hunger due to climate change, although already larger proportion, Africa may account for the majority by the 2080s (Fischer et al. 2002). The increase in inerratic rainfall seasons characterized by unpredictable length of seasons, high temperatures alternating floods and dry spells, and variable rainfall amounts presents new 
Table 1 Agro-ecological regions and potential land use for Zimbabwe

\begin{tabular}{l|c|l|l|l}
\hline $\begin{array}{l}\text { Agro- } \\
\text { ecological } \\
\text { zone }\end{array}$ & Area (ha) & $\begin{array}{l}\text { Area as } \\
\% \text { of } \\
\text { country }\end{array}$ & Characteristic weather & $\begin{array}{l}\text { Recommended land } \\
\text { use }\end{array}$ \\
\hline I & 703,400 & 1.8 & $\begin{array}{l}\text { High rainfall }>900 \mathrm{~mm} \text { per } \\
\text { annum), with some } \\
\text { precipitation throughout the } \\
\text { year. Low temperatures }\end{array}$ & $\begin{array}{l}\text { Fruits, tea, coffee } \\
\text { macadamia nuts, } \\
\text { intensive livestock } \\
\text { production }\end{array}$ \\
\hline II & $5,861,400$ & 15.1 & $\begin{array}{l}\text { Moderately high }(750- \\
1000 \text { mm per annum) rainfall } \\
\text { confined to summer. Severe } \\
\text { dry spells are rare }\end{array}$ & $\begin{array}{l}\text { Intensive crop and/or } \\
\text { livestock production }\end{array}$ \\
\hline III & $7,287,700$ & 19.5 & $\begin{array}{l}\text { Infrequent heavy rainfall } \\
\text { leads to moderate annual } \\
\text { recording of about } 650- \\
800 \text { mm. Fairly severe } \\
\text { mid-season dry spells }\end{array}$ & $\begin{array}{l}\text { Marginal for maize, } \\
\text { tobacco, and cotton } \\
\text { production, livestock } \\
\text { production }\end{array}$ \\
\hline IV & $14,782,300$ & 36.7 & $\begin{array}{l}\text { Fairly low total rainfall } \\
\text { (450-650 mm per annum). } \\
\text { Periodic seasonal droughts, } \\
\text { severe dry spells during rainy } \\
\text { season }\end{array}$ & $\begin{array}{l}\text { Drought resistant crops } \\
\text { such as sorghum and } \\
\text { pearl millet, livestock } \\
\text { production }\end{array}$ \\
\hline V & $10,441,100$ & 26.8 & $\begin{array}{l}\text { Low and erratic rainfall } \\
\text { (<450 mm per annum, } \\
<650 \text { mm in the Zambezi } \\
\text { valley, and }<600 \text { mm in the } \\
\text { Sabi-Limpopo Valleys). } \\
\text { Prolonged midterm dry } \\
\text { spells }\end{array}$ & $\begin{array}{l}\text { Too dry for successful } \\
\text { crop production } \\
\text { without irrigation. } \\
\text { Marginal millet, } \\
\text { sorghum, extensive } \\
\text { beef ranching, game } \\
\text { ranching }\end{array}$ \\
\hline
\end{tabular}

challenges to the majority of the farmers in the absence of appropriate response strategy (Zimbabwe climate change response strategy, 2017). In the 2018-2019 cropping season below normal and highly erratic and patchy rainfall was recorded for the first half of the season and most crops were stressed with most being completely written off because of prolonged dryness (FEWS Net 2019).

In Zimbabwe, over 70\% of Zimbabwe's employment is directly or indirectly accounted for by agriculture. The national agricultural production largely relies on rain-fed agriculture which is one of the most vulnerable sectors to climate change and variability. Adaptation to climate change will entail adjustments and changes at every level from community to national level. Communities must build their resilience including adapting appropriate technologies while making the most of traditionally and locally generated technologies and diversifying their livelihoods to cope with the current and future stresses (Fischer et al. 2002).

Zimbabwe is generally characterized by low rainfall and more than $50 \%$ of its land area falls under region IV and $\mathrm{V}$ which receive rainfall lower that $650 \mathrm{~mm}$ per season (Table 1).

Maize planted late will not give good yields, thus making maize production a less viable activity under climate change conditions. In the low-lying areas of southern 
(A) current

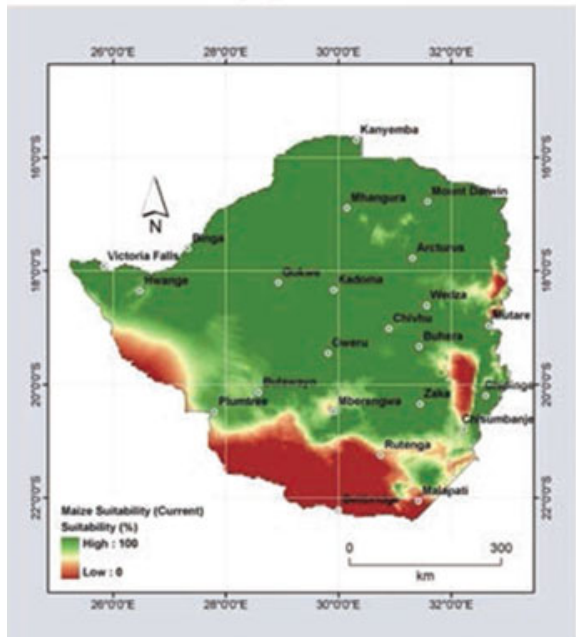

(B) worst case 2080

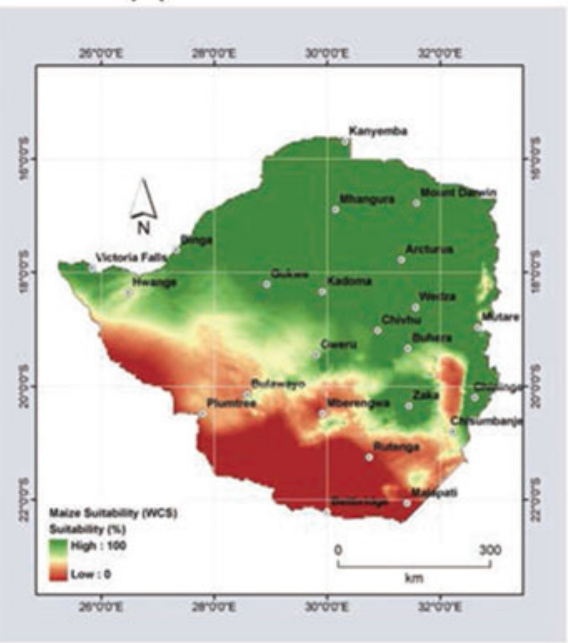

Fig. 1 A comparison of the maize production zones under the current and worst case scenario for the year 2080. (Source: Zimbabwe's Second Communication to the United Nations framework convention on climate change (UNFCCC))

Zimbabwe, for example, it is probable that climate change will turn the region into a non-maize-producing area, as exemplified by reduced maize production in Masvingo (Fig. 1). The projections are that by 2080 the area suitable for maize production in the south-western and central provinces of Zimbabwe will have decreased (Fig. 1).

This area, which represents $42 \%$ of the communal area, will become even more marginal for maize production. Based on site results, seasons could be $25 \%$ shorter than now.

Communities living in natural regions IV and $\mathrm{V}$ (which make up about $64 \%$ of the land area) are at the mercy of climatic extremes, with few livelihood options (Brazier 2015). They tend to be the most vulnerable to poverty. These regions are already feeling the impacts of climate change and will be the hardest hit in the future. Climate change will exacerbate hardship and poverty among the people of Zimbabwe. Women, children, and the disabled, especially those living in rural areas, will be the worst affected. The causes of rural poverty relate to the adverse climate and environmental conditions that disrupt agriculture, the main livelihood activity in areas where most people live. Women, children, the elderly and the disabled have been identified in several studies as being the most vulnerable to shocks. Zimbabwe's agricultural systems are already insecure as they depend mainly on seasonal rainfall. In addition, ruinous land use practices in the form of poor soil and water management, reduced biodiversity, and poor choice of crops to plant have led to degradation of the resource based on which agriculture depends. Climate change will hasten the degradation and exacerbate food insecurity, which is already 
Table 2 The impacts, sectorial vulnerabilities, and adaptive capacity to climate change

\begin{tabular}{l|l|l}
\hline Impacts & Sectorial vulnerability & Adaptive capacity \\
\hline Warning by $1.5^{\circ} \mathrm{C}$ & $\begin{array}{l}\text { Agricultural } \\
\text { production severely } \\
\text { compromised }\end{array}$ & Rainwater harvesting \\
\hline Drier subtropical regions & $\begin{array}{l}\text { Uncertainty on what } \\
\text { and when to plant }\end{array}$ & $\begin{array}{l}\text { Improved varieties that } \\
\text { fit into the current } \\
\text { seasons }\end{array}$ \\
\hline Decrease in annual rainfall & $\begin{array}{l}\text { Yields from rain-fed } \\
\text { production can be } \\
\text { halved }\end{array}$ & \\
\hline $\begin{array}{l}\text { Extreme events: increase in frequency and } \\
\text { intensity of storms and droughts and floods }\end{array}$ & $\begin{array}{l}\text { Net revenue could fall } \\
\text { by } 90 \% \text { by } 2100\end{array}$ & \\
\hline
\end{tabular}

Adapted and modified from Christensen et al. (2007)

prevalent in Zimbabwe. There are likely to be shifts in the start and end of the rainy season, and the onset of the rains may be delayed by between 4 and 6 weeks. This will mean changes in planting and harvesting dates, the length of the growing season, and the types of crops that farmers are forced to adopt.

Climate change affects crop production in the following ways (Table 2).

\section{Characteristics of Cotton Growing Areas in Zimbabwe}

The farms are generally small, often held under traditional tenure and are located in marginal areas which are risk prone (FAO 2012). Their challenge is to improve production of cotton under climate change. The investments in farming are low and their ability to adapt is very low. The inventions in this sector have to low cost so that adaptation levels are high hence the introduction of tied ridges and use of imported varieties for sustainable cotton production. Varieties purchase will be done by everybody prior to the onset of the season. Tied ridges are not an expensive technology to introduce to the farmers as long as they understand the merits.

\section{Crop Genetic Diversity and Climate Change}

The emerging changes in climate will force farmers to adopt new varieties and crop types and forms of agricultural production technologies that can respond to new and changing stress factors. The areas that are currently the most food insecure will be worst affected and will have the greatest need for new crop varieties that are tolerant to drought high temperatures flooding salinity and other environmental extremes (FAO 2015). Diverse crop species, varieties, and cultivation practices allow crops to be grown across a wide range of environments. Sometimes better adapted varieties will need to be brought in from outside. 
Traits that contribute to phenotypic plasticity (ability to cope with a wide range of environmental conditions) may be increasingly important. Such is the case with cotton in Zimbabwe where the traditional varieties were complimented by imports of new cotton seed varieties from India.

Genetic resources could contribute greatly to efforts to cope with climate change. It is likely that climate change will necessitate more international exchanges of genetic resources as countries seek to obtain well-adapted crops. There is likely going to be a greater interdependence on the use of genetic resources and that underscores the importance of international cooperation (FAO 2015).

Food-insecure people in the developing world such as Zimbabwe especially women and indigenous people are among the most vulnerable groups and usually the hardest hit. In the case of cotton, the varieties used in Zimbabwe were not of a match to the current environmental characteristics. Zimbabwe farmers continued to cultivate the varieties although they were poorly adapted to the environment. The Cotton Company of Zimbabwe imported hybrid varieties from India with the objective of improving productivity and helping farmers to cope with environmental adversities.

\section{Status of Cotton}

Cotton is the second most important cash crop in Zimbabwe and is grown by thousands of smallholder farmers on average plot sizes of about 1 ha in the summer growing season (Global Agricultural Information Network 2017). The crop is strategic for poverty alleviation and is of major significance to food security for smallholder farmers in marginal areas due to its contribution to incomes and employment (Mujeyi 2013). The crop supports over one million people in marginal areas of Zimbabwe including farmers their families, farm workers, and industrial workers (Buka 2017; Mujeyi 2013). Most cotton growers have limited opportunities as these are in semiarid areas and cotton production is the only viable option.

However, cotton production has been on the decrease in terms of the number of farmers producing the crop (Fig. 2).

In some yeas the government intervened in cotton production through free cotton inputs. Generally the trend from the number of cotton farmers to yield per hectare (Figs. 2 and 3) points to the fact that cotton production is in the decrease. This might be partly due to the low prices on the international market. The low levels of production might be partly due to old varieties which are poorly adapted to the current environmental trends as dictated by climate change. There have been no new cotton varieties over the past 25 years in Zimbabwe. This implies that the recent climate shifts experienced in most parts of the world has not been factored in Zimbabwe cotton breeding program. The government of Zimbabwe prohibited the use of genetically modified seed which might have improved cotton yields.

Climate change has brought greater uncertainty and exposure to multiple climate stress. The lives of millions of people in semiarid Zimbabwe who depended on 


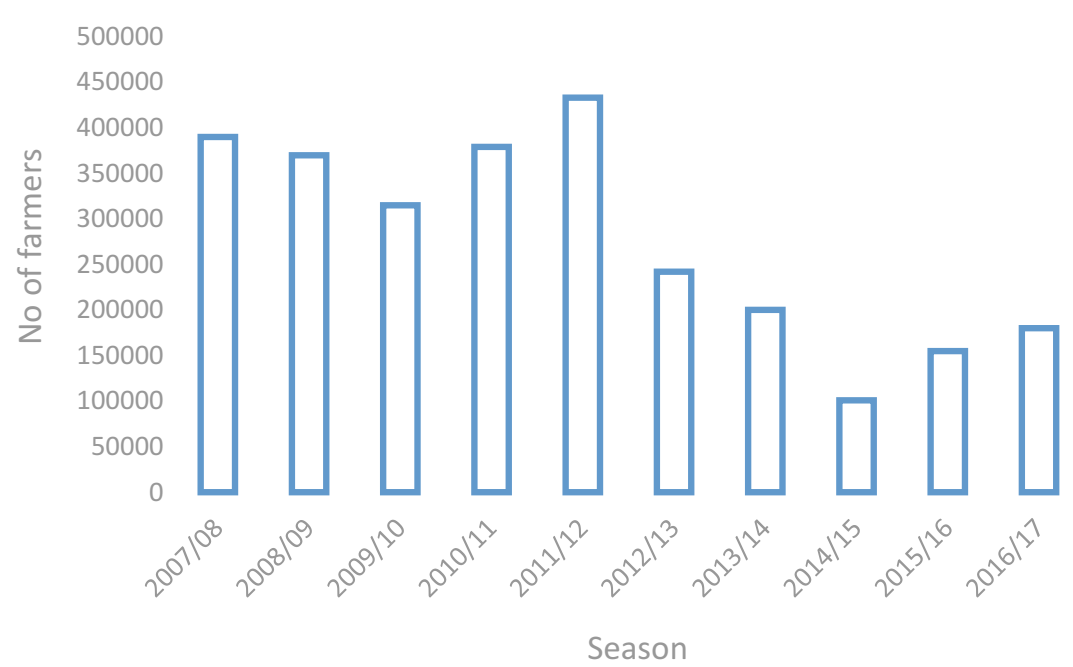

Fig. 2 Number of farmers cultivating cotton from 2007/08 season to 2016/17 season in Zimbabwe

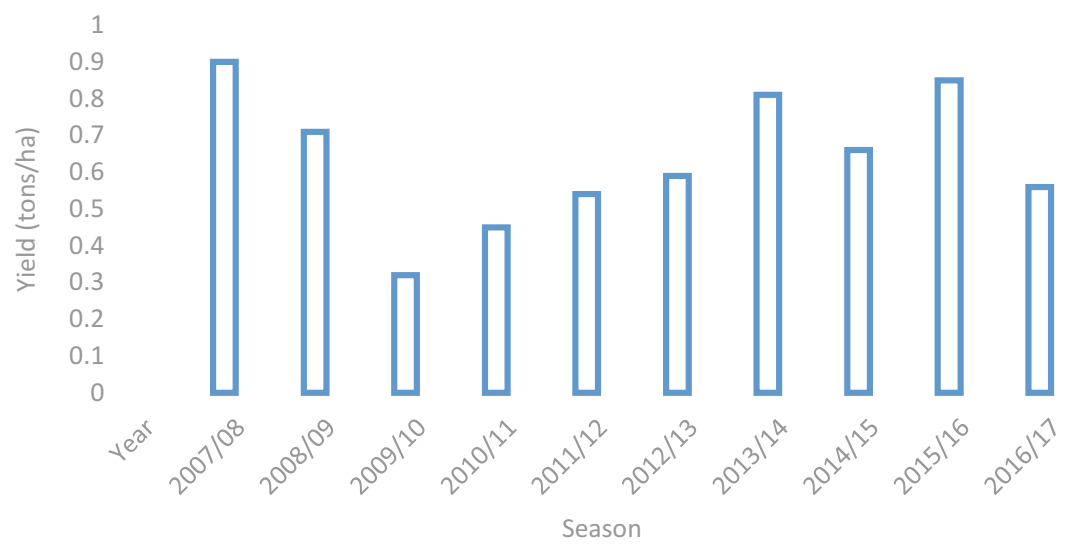

Fig. 3 Average yield of cotton (t/ha) from 2007/08 to 2016/17

cotton for their livelihood are highly vulnerable to climate change. The local farmers have traditionally managed harsh environment by growing moisture stress-tolerant cotton. In order to improve the effectiveness of crop production in these marginal rainfall regions, cultural practices which conserve water availability to the crop are essential (Mupangwa et al. 2006).

Investing in agricultural production methods to boost farmers' resilience against weather shocks is a key strategy to reduce negative impacts. The cotton growing areas of Zimbabwe are generally rain fed and are characterized by rainfall patterns which are highly variable in amount and distribution. This has been exacerbated by 
climate change. According to McHugh et al. (2007), the main limitation for increasing crop yields in rain-fed farming systems is crop water stress caused by inefficient use of rainwater. Rockstrom and Falkenmark (2000) reported that inefficient use of rainwater is often a consequence of poor rainfall partitioning resulting in low rootzone soil moisture or poor plant uptake of available moisture. Making rainfall available and its effective storage and efficient use are therefore important adaptive mechanisms and major determinants in cotton production under climate change. According to Nyamadzawo et al. (2013), climate change models have projected a decrease in rainfall in southern Africa and research has already shown the same. Therefore, the focus should be on upgrading rain-fed smallholder farming in tropical environments characterized by frequent droughts and mid-season dry spells. According to Ibraimo and Munguambe (2007), there is need for more efficient capture and use of scarce water resources in arid and semiarid areas. The optimization of rainfall management through water harvesting in sustainable and integrated production system can contribute to improve small scale farming households by upgrading rain-fed agricultural production. Research has documented substantial increases that are obtained through soil water conservation and efficient use of it by the crop, and, subsequently, the yield increases.

\section{In-Field Moisture Harvesting}

\section{Tied Ridges}

The effect of the ridges was generally higher in drier periods and more when the ridge ends were tied. Belay et al. (1998) reported that in wetter seasons, open-end ridges gave higher yields which show how important it is that soil and land management practices include means to safely dispose water from the field, should the rain exceed the retention of the soil. UNEP (1997) also confirmed that rain water harvesting involves the use of methods that increase the amount of water stored in the soil profile by trapping or holding the rain where it falls and it involves small movements of rainwater in order to concentrate it where it is required.

\section{Planting Basins}

In Zimbabwe, planting basins are structures that are dug from July through October in the same positions annually and whose recommended dimensions are $15 \mathrm{~cm}$ length by $15 \mathrm{~cm}$ width and $15 \mathrm{~cm}$ depth (Mupangwa et al. 2006; Twomlow and Hove 2007). These basins are spaced at $90 \mathrm{~cm}$ by $60 \mathrm{~cm}$. The basins benefit, particularly, poorer farmers with no access to draught power as they will not have delayed planting as they wait to borrow draught power from their neighbors (Mazvimavi and Twomlow 2007). 


\section{Mulch Ripping}

Ox-drawn rip lines are made from attachments fitted on the plough frame and were developed to open furrows for moisture capture. They also break superficially compacted layers (Mandumbu 2011). Mapfumo et al. (2002) explained that mulch ripping makes use of the soil on the surface to protect the soil underneath, making soil disturbance limited to the planting zones, and ripping is done to a depth of $23 \mathrm{~cm}$. In Zimbabwe, rip lines that are being promoted go to a depth of $23 \mathrm{~cm}$.

\section{Cotton Production Under Climate Change}

Drought-tolerant cotton and in-field water harvesting are promising technologies to minimize the impacts of drought (Katengeza et al. 2019). The farmers in Zambezi valley in Zimbabwe have traditionally used two cotton varieties. Although these have over the years sufficed, they are currently failing due to recent trends on climate change. The low cotton genetic diversity and its use in traditional risk management may affect the resilience of farmers especially recently due to existing stresses which have made the environment more unpredictable (Meldrum et al. 2017). According to Thomas et al. (2015) the importance of crop genetic diversity or resilience and adaptation of farm systems to climate change is highlighted in many studies.

Recently, the cotton companies have promoted subsoiling and tied contours as in-field water harvesting techniques to cushion farmers against the adverse effects of climate change (Chaniwa et al. 2020). In situ water harvesting involves small movements of rainwater as surface runoff, in order to concentrate water where it is wanted most (Ibraimo and Munguambe 2007). Therefore the objectives of this study are to determine the effects of two tillage systems (conventional and tied ridges) on the performance of six cotton genotypes in semiarid northern Zimbabwe.

\section{Effects of Water Harvesting on Soil Moisture Content}

The results showed that tied rides had a significantly higher $(P<0.05)$ moisture content in the $0-5$ and 6-10 cm depth compared to conventional system, while there were no significant differences between the two tillage systems at $11-15 \mathrm{~cm}$ (Fig. 4).

The results indicated that tied ridges had significantly higher percentage of moisture content at $0-5$ and $6-10$ but not at $11-15 \mathrm{~cm}$. Higher moisture content at $0-5 \mathrm{~cm}$ illustrates the effectiveness of tied contours in moisture conservation on top soil horizons. The 2018-2019 season was a drought year in Zimbabwe, so the effects of the tillage method on moisture was apparent. These results are in tandem with Mupangwa et al. (2006) and Nyamadzawo et al. (2013) who reported the efficiency of tied ridges in capturing moisture and concentrating it on the root zone. Usually shallower depths are first ones to dry, hence the ability of the tied ridges to retain moisture makes the crop grow better compared to those in conventional plots; as the season was characterized by short duration, high-intensity rainfall, this might have 


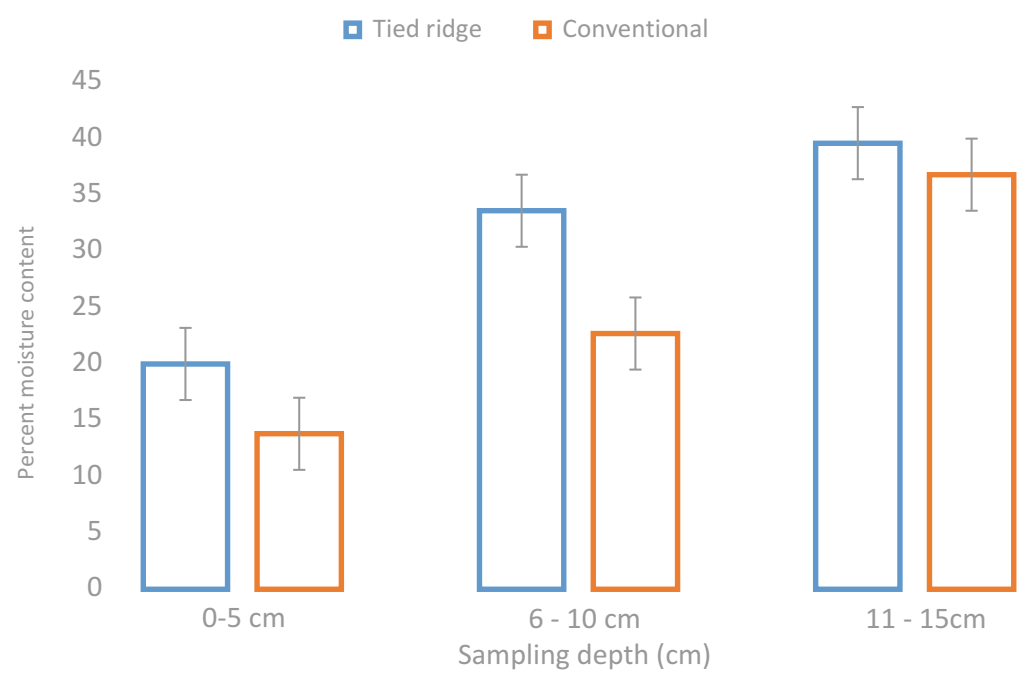

Fig. 4 Effects of tillage system on percentage moisture content at three sampling depths

resulted in moisture loss through runoff as rainfall intensity exceeded the infiltration capacity of the soil.

This means that the use of tied ridges as moisture conservation techniques was advantageous in the cotton as plants grown in tied ridges could still absorb moisture from the top horizons while those in conventional tillage could not. Higher moisture content will be followed by higher water use efficiency and subsequently higher yields. Promoting such a technology in the communities located in marginally drier areas would increase productivity of the cotton plants and help farmers cope with dryness caused by climate change.

Tied ridges increase the amount of water in the soil profile by trapping or holding the rainfall. These structures reduce runoff from the fields and enhance infiltration. This leads to higher amounts of stored moisture. Water harvesting is currently being rejuvenated in the marginal areas as an adaptive mechanism to climate change. Highintensity rainfall causes moisture to be lost through runoff. Research done by Nyamadzawo et al. (2012) found moisture losses as much as $50 \%$ being lost to runoff from cultivated fields. Due to the erratic nature of the rainfall such losses may never be recovered.

Soil water content near field capacity allows for best combinations of sufficient air space for oxygen diffusion, greatest amounts of nutrients in soluble forms, greatest cross-sectional areas for diffusion of ions and mass flow of water, and most favorable conditions for root extension.

The days to flowering varied significantly due to the effects of cotton genotypes. The results indicated that the genotypes M579 and M 577 had significantly fewer days to flowering compared to QM301 and CRIM 51 which are the Zimbabwe varieties (Fig. 5). 


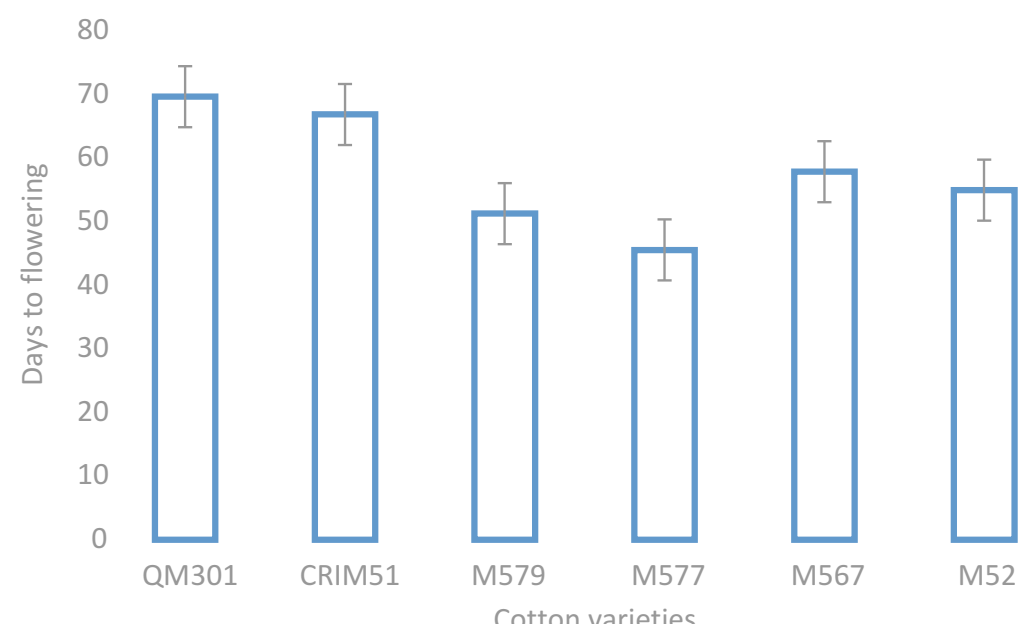

Fig. 5 The effect of cotton varieties on days to flowering

It was observed that M579 and M577 flowered the earliest compared to the rest of the varieties (Fig. 2). The variety M577 had the highest number of productive branches (Fig. 2). This according to Kooyers (2015) illustrates drought escape. Drought escape occurs when plants develop rapidly and reproduce when the environment becomes severe. Usually a variety that develops early escapes drought due to the shortened life cycle. The early flowering varieties represent a response when the plant's genetic resources are sourced to assist farmers to adapt to the changed climate. FAO (2015) reported that the biggest challenge for future food or commerce is to find a good match between the crops and the production environment as the effects of climate change increase. The two varieties are therefore suited to the changed conditions of semiarid Zimbabwe. These genotypes were obtained from India. Singh (2017) reported that one of the breeding strategies to mitigate the effect of climate change is to improve adaptation through increased access to a number of varieties at the local level with different growth durations to escape or to avoid predictable occurrences of stress at critical periods. This reduces the vulnerability of local farmers to the effects of climate change extremes.

The cotton variety M577 had the biggest cotton branch number compared to the rest of the varieties. The locally bred varieties showed lower branch numbers compared to the imported one (Fig. 6).

Branch number was also significantly $(P<0.05)$ affected by moisture conservation method. Tied ridges had significantly higher branch number compared to conventional tillage (Fig. 6).

The hybrids showed potential for use in environments with low water availability. Obtaining hybrids with good grain yield in environments with water restriction and a significant increase in water-limited environments has been an aim of many breeding 


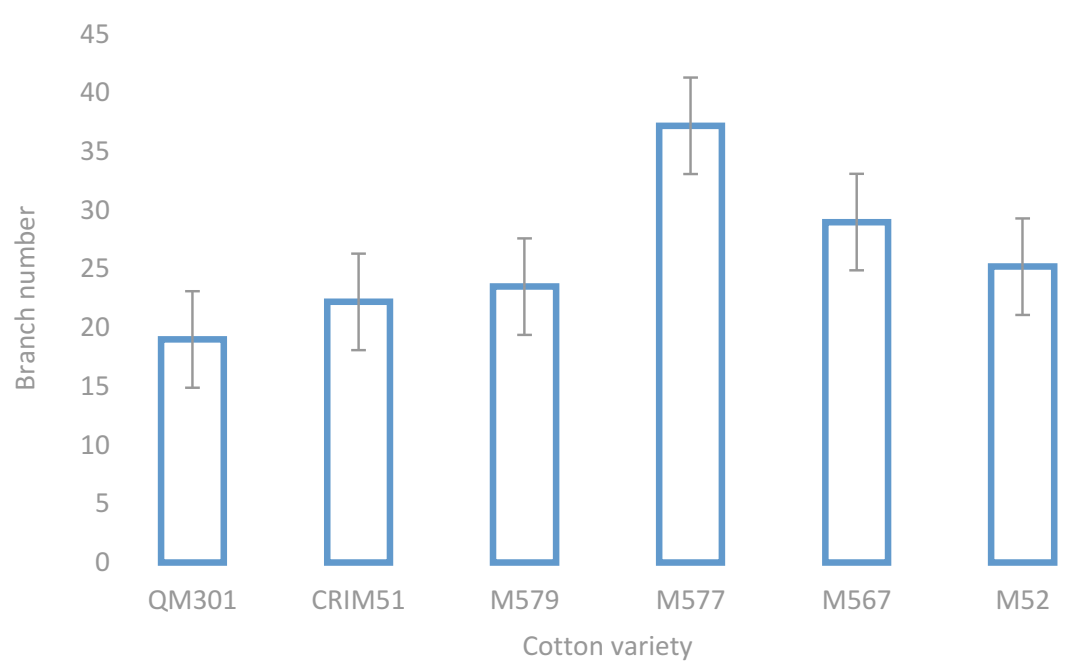

Fig. 6 The effect of cotton varieties on branch number

Fig. 7 Effect of tillage method on cotton branch number

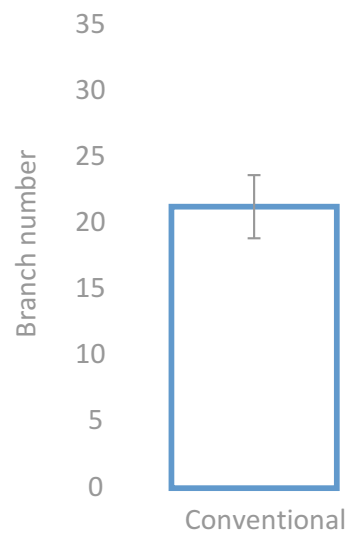

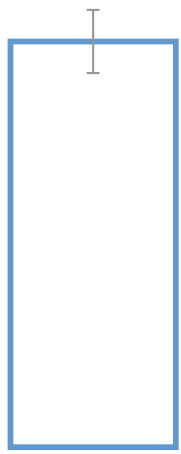

Tied contour

programs. Varieties with lower yield reduction in stressful environment mean stability of production which is desirable.

A combination of high bearing branch number and few days to flowering is key in selecting crop varieties suited to climate change. One major characteristic of the seasons is erratic rainfall which begins early and terminates prematurely. Other seasons have delayed start and end prematurely. Generally, most seasons are not long enough to allow most varieties from germination until it reaches maturity. The varieties M577 and M567 suit such an environment as it can escape droughts through early phenological development. Quicker production of flowering branches also indicates tolerance to drought. Therefore, introduction of varieties to small-scale farmers in Zimbabwe is for farmers' adaptation to climate change. 
For flower number the M577, M579, and M567 had the highest number of flowers. Flower number represents reproductive capacity. The same trend was observed on boll number. Higher flower numbers were observed on tied ridges compared to conventional system (Fig. 7). This showed that the varieties respond to tied ridges compared to conventional. As cotton is grown by small-scale farmers in high-risk environments, the results illustrate the suitability of these three varieties to the northern Zimbabwe environment. Adopting the three varieties to the Zimbabwean conditions illustrate Nhemachena et al. (2016)'s assertion that new crop varieties will be needed to cope with climate change. Areas with shortened seasons result in low yield potential, affecting agricultural productivity. Local breeding efforts may be slow to match the changing environments, hence the importation of genotypes that suit the environment. The new environment is forcing farmers to abandon some varieties or even abandon the crop especially if the varieties cannot withstand the new conditions.

The tied ridges gave a significantly higher branch number compared to conventional system (Fig. 5). This illustrates the suitability of the moisture conservation to maintain cotton production in arid areas which are vulnerable to climate change. Tied ridges tended to concentrate moisture on the few areas and that makes more moisture available for the crop.

The varieties M579 and M577 were the most suited to the climate of northern Zimbabwe as they performed much better that the traditional varieties which farmers have been using. Also making tied ridges improve water retention properties of the soil and leads to greater water use efficiency. Therefore adoption of tied ridges and the two varieties has potential to be an adaptive strategy that has potential to resuscitate an industry that was facing extinction due to climate change. Bringing new varieties and introducing water harvesting has been key in alleviating the effects of climate change on cotton production. The current conventional cotton varieties had failed to cope with climate change effects of reduced moisture availability. Other characteristics noted on the new varieties were very early development and increased branch number. These new varieties are better able to withstand the current adversities and keep marginalized farmers in production. The number of bolls noted per branch and on branches is all yield parameters which are critical for cotton productivity.

The cotton parameters noted above contribute to phenotypic plasticity which is the ability to cope with a wide range of environmental conditions. According to Kooyers (2015), drought escape may be optimal for annual plants in environments with shorter growing periods that are ended by sever terminal drought while drought avoidance may be optimal where if the growing season is punctuated by transient droughts.

\section{References}

Belay A, Gebrekidan H, Uloro Y (1998) Effect of tied ridges on grain yield response of Maize (Zeamays L.) to application of crop residue and residual $\mathrm{N}$ and $\mathrm{P}$ on two soil types at Alemaya, Ethiopia. S Afr J Plant Soil 15(4):123-129. https://doi.org/10.1080/02571862.1998.10635130

Brazier A (2015) Climate change in Zimbabwe: facts for planners and decision makers. KonradAdenauer-Stiftung, Harare

Buka G (2017) Cotton and its by-products sector in Zimbabwe. UNCTAD, Geneva 
Chaniwa M, Nyawenze C, Mandumbu R, Mutsiveri G, Gadzirayi CT, Munyati VT, Rugare JT (2020). Ending poverty through affordable credit to small scale farmers: the case of Cotton Company of Zimbabwe. In: Nhamo et al. (eds) Scaling up SDGs implementation. Sustainable development goals series. https://doi.org/10.1007/978-3-33216-7_8

Christensen JH, Hewitson B, Busuioc A, Chen A, Gao X, Held I, Jones R, Kolli RK, Kwon W-T, Laprise R, Magaña Rueda V, Mearns L, Menéndez CG, Räisänen J, Rinke A, Sarr A, Whetton P (2007) Regional climate projections. In: Solomon S, Qin D, Manning M, Chen Z, Marquis M, Averyt KB, Tignor M, Miller HL (eds) Climate change 2007: the physical science basis. Contribution of working group I to the fourth assessment report of the intergovernmental panel on climate change. Cambridge University Press, Cambridge, UK/New York

FAO (2012) Climate change adaptation and mitigation. FAO, Rome

FAO (2015) Coping with climate change-the role of genetic resources for food and agriculture. FAO, Rome

FEWSNET (2019) Late and below normal rains and economic hardships expected to impact poor households food access. USAID

Fischer G, Shah M, van Velthuizen H (2002) Climate change and agricultural variability, a special report, on Climate change and agricultural vulnerability, contribution to the world summit on sustainable development. Johannesburg 2002 (Global, agriculture)

Global Agricultural Information Network (2017) Cotton production and consumption in Zimbabwe. USDA Foreign Agric Service

Ibraimo N and Munguambe P (2007) rainwater harvesting technologies for small scale rainfed agriculture in arid and semi-arid areas. Paper presented at the Integrated water resource management for improved livelihoods. CGIAR challenge program on water and food. South Africa

Katengeza SP, Holden ST, Lunduka RW (2019) Adoption of drought tolerant maize varieties under rainfall stress in Malawi. J Agric Econ 70:198-214

Kooyers NJ (2015) The evolution of drought escape and avoidance in natural herbaceous populations. Plant Sci 234:155-162

Mandumbu R (2011) Seedbank dynamics in conservation agriculture in south western Zimbabwe. Lambert Academic Publishers, Germany

Mapfumo P, Chuma E, Nyagumbo I, Mutambanengwe F (2002) Farmer field schools: facilitator manual; integrated soil water and nutrient management in semi-arid Zimbabwe. FAO of UN, Zimbabwe

Mazvimavi K, Twomlow SJ (2007) Conservation farming for agricultural relief and development in Zimbabwe. ICRISAT, Matopos Research Station, Bulawayo

McHugh OV, Steenhuis TS, Abebe B, Fernandes ECM (2007) Performance of in situ rainwater conservation tillage techniques on dry spell mitigation and erosion control in the drought-prone North Wello zone of the Ethiopian highlands. Soil Tillage Res 97:19-36

Meldrum G, Mijativic D, Rojas W, Flores J, Pinto M, Mamani G, Condori E, Hilaquith D, Grumberg H, Pdulosi S (2017) Climate change and crop diversity: farmers' perception and adaptation on the Bolivian Altipano. Environ Dev Sustain. https://doi.org/10.1007/s10668-016-9906-4

Mujeyi K (2013) Viability analysis of smallholder cotton production under contract farming in Zimbabwe. Invited paper presented at the 4th international conference of the African association of agricultural economists, September 22-25, 2013, Hammamet

Mupangwa W, Love D, Twomlow SJ (2006) Soil water conservation and rainwater harvesting strategies in semi-arid Mzingwane catchment Limpopo Basin, Zimbabwe. Phys Chem Chem. https://doi.org/10.1016/jpce.2006.08.042

Nhemachena C, Matchaya G, Nhlengetwa S, Nhemachena CR (2016) Economic aspects of genetic resources in addressing agricultural productivity in the context of climate change. In: Lal $\mathrm{R}$ et al (eds) Climate change and multidimensional sustainability in African agriculture. https://doi.org/ 10.1007/978-3-319-41238-2_9

Nyamadzawo G, Nyamugafata P, Wuta M, Nyamangara J, Chikowo R (2012) Infiltration and runoff losses under fallowing and conservation agriculture practices on contrasting soils, Zimbabwe. Water SA 38(2):233-240 
Nyamadzawo G, Wuta M, Nyamangara J, Gumbo D (2013). Opportunities for optimisation of infield water harvesting to cope with changing climate in semi-arid smallholder farming areas of Zimbabwe. Springer Plus 2:100

Rockstro"m J, Falkenmark M (2000) Semiarid crop production from a hydrological perspective: gap between potential and actual yields. Crit Rev Plant Sci 19:319-346

Singh RP (2017) Improving seed systems resiliency and local level through participatory approaches to adaptation to climate change. Adv Plants Agric Res 6:15-16

Thomas M, Thepot S, Galic N, Jovanne-Pin S, Remone C, Goldringer I (2015) Diversifying mechanisms in the on-farm evolution of crop mixtures. Mol Ecol 24:2937-2954

Twomlow SJ, Hove L (2007) Is conservation agriculture an option for vulnerable households in southern Africa. Paper presented at the conservation agriculture for sustainable land management to improve livelihoods for people in dry areas workshop, 7-9 May 2007, Damascus

UNEP (1997) Source book of alternative technologies for fresh water augmentation in Latin America and the Caribbean. International Environmental Technology Center, United Nations Environment Programme, Washington, DC

UNFCCC (2007) Climate change impacts, vulnerabilities and adaptation in developing countries. UNFCCC, Bonn

Open Access This chapter is licensed under the terms of the Creative Commons Attribution 4.0 International License (http://creativecommons.org/licenses/by/4.0/), which permits use, sharing, adaptation, distribution and reproduction in any medium or format, as long as you give appropriate credit to the original author(s) and the source, provide a link to the Creative Commons license and indicate if changes were made.

The images or other third party material in this chapter are included in the chapter's Creative Commons license, unless indicated otherwise in a credit line to the material. If material is not included in the chapter's Creative Commons license and your intended use is not permitted by statutory regulation or exceeds the permitted use, you will need to obtain permission directly from the copyright holder.

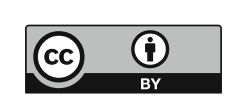

